\title{
PENINGKATAN INTERAKSI DAN PRESTASI SISWA SMK MELALUI APLIKASI PEMBELAJARAN PROBLEM SOLVING
}

\author{
Muhammad Firdzaus K., M. Akhyar, Suharno \\ Prodi. Pendidikan Teknik Mesin, Jurusan Pendidikan Teknik dan Kejuruan, FKIP, UNS \\ Kampus UNS Pabelan, Jl. Ahmad Yani 200, Surakarta, Tlp/Fax 0271718419 \\ E-mail : myharno@yahoo.com
}

\begin{abstract}
The purpose of this research improves activeness and learning outcomes of student XI TO B class on learning theory at automotive electrical lesson SMK Negeri 5 Surakarta for academic year 2012/2013. This data the research were activeness and learning outcomes of student. The Collecting of the data by using four ways, there was interview, observation, test, and questionaire. The observation sheet use six indicators of activeness : asking, argue, listening, reading, writing, and discussion. The data of the research was analyzed with descriptive analyse techniques. The research includes action research in education, namely classroom action research (PTK). This research was by one meeting activities before the cycle. PTK was carried out with two cycle's, each cycle two meeting's with one test in last of second meeting. Based on the result, result of research was concluded that application of Problem Solving Learning Method improved 9,25\% activeness of student XI TO B class on learning theory at automotive electrical lesson SMK Negeri 5 Surakarta for academic year 2012/2013. Beside that application of Problem Solving Learning Method improved learning outcome of student XI TO B class on learning theory at automotive electrical lesson SMK Negeri 5 Surakarta for academic year $2012 / 2013$.
\end{abstract}

Keywords : problem solving, student activeness, learning outcomes, automotive electrical.

\section{PENDAHULUAN}

Tujuan pendidikan kejuruan adalah membekali siswa agar memiliki kompetensi perilaku dalam bidang kejuruan tertentu sehingga yang bersangkutan mampu bekerja (memiliki kinerja) demi masa depan dan untuk kesejahteraan bangsa (Chippers \& Patriana, 1993). Untuk mencapai tujuan tersebut maka pembelajaran yang baik merupakan hal yang sangat diperhatikan. Pembelajaran di SMK terbagi dua pembelajaran teori dan pembelajaran praktik, keduaduanya harus seiring dan senantiasa melengkapi. Pembelajaran praktik tidak akan efektif sebelum didahului dengan teori, sedangkan pelajaran teori tidak akan mendalam pemahamannya tanpa adanya praktik langsung.

SMK Negeri 5 Surakarta merupakan salah satu sekolah unggulan di Surakarta. Hal ini terbukti dengan siswa SMK Negeri 5 Surakarta ikut andil dalam mengembangkan perakitan kendaraan merek "ESEMKA". Keberadaannya sebagai salah satu sekolah unggulan di Surakarta mengharuskan sekolah ini untuk senantiasa mengadakan perbaikan-perbaikan agar kualitas pembelajarannya meningkat.

Kelas XI TOB merupakan salah satu kelas dari Program Studi Keahlian Teknik Otomotif di SMK Negeri 5 Surakarta. Kelas ini diduga termasuk kelas yang rendah tingkat perhatian dan partisipasinya dibanding kelas yang lain dalam pembelajaran teori, terkhusus lagi pada pelajaran kelistrikan otomotif. Berdasarkan pengamatan pada kegiatan prasiklus, dalam pembelajarannya banyak siswa yang kurang memperhatikan guru dan suka ramai sendiri, terlihat keaktifan mereka dalam pembelajaran masih kurang.
Hasil belajar siswa XI TOB sampai akhir uji kompetensi ketiga, baru sekitar 55\% yang mencapai Kriteria Ketuntasan Minimum (KKM) sedangkan sisanya $45 \%$ belum mencapai KKM, jelas hal ini perlu untuk ditingkatkan. Kegiatan cerama lebih mendominasi pembelajaran teori, akibatnya siswa merasa jenuh, tidak menaruh perhatian, dan akhirnya keaktifan mereka untuk terlibat dalam pembelajaran menjadi kurang. Hal ini tentu akan berdampak pula pada pembelajaran praktek siswa nantinya.

Keaktifan siswa yang kurang dalam pembelajaran teori kemungkinan disebabkan antara lain metode pembelajaran yang jarang diperhatikan, metode yang lebih cenderung pada penyampaian materi saja, kemungkinan akan membuat siswa merasa jenuh, Berbeda halnya jika metode yang digunakan memberikan siswa suatu masalah, akan membuat siswa lebih tertantang dan termotivasi untuk memperhatikan selama pembelajaran berlangsung. Untuk itu dibutuhkan suatu pengaturan pembelajaran diantaranya dengan penerapan metode pembelajaran problem solving dan makalah ini menyajikan penerapan pembelajaran problem solving pada pembelajaran teori pelajaran kelistrikan otomotif kelas XI TOB SMK Negeri 5 Surakarta.

\section{Landasan Teori}

Berdasarkan asal katanya arti kata aktif adalah giat; gigih; dinamis atau bertenaga; mampu beraksi dan bereaksi. Sedangkan keaktifan ialah kegiatan; kesibukan (Suharso \& Retnoningsih, 2009). Sehingga bisa dikatakan bahwa keaktifan siswa 
merupakan kegiatan/ kesibukan mereka selama proses pembelajaran.

Terdapat empat dasar kegiatan siswa dalam pembelajaran yaitu; a) berbicara dan mendengarkan; b) menulis; c) membaca, dan; d) merefleksi (Center of Teaching and Learning/ CTL, 2008).

Dalam pembelajaran keaktifan berbicara dapat berupa beberapa hal, diantaranya bertanya dan berpendapat. Sedangkan untuk mendengar dapat berupa kegiatan siswa menyimak pelajaran. Menulis merupakan penuangan gagasan, pemahaman ke dalam bentuk tulisan. Membaca merupakan salah satu daya dukung bagi siswa untuk memahami pelajaran. Dalam kegiatan membaca siswa melakukan kegiatan berpikir dalam mengolah informasi. Adapun untuk memahami pelajaran lebih jauh siswa, membutuhkan waktu mencerminkan antara informasi baru yang diperoleh dengan pengalaman yang sudah ada sebelumnya dengan merefleksi. Selama kegiatan pembelajaran merefleksi cukup sulit untuk dilihat secara langsung, karena berkenaan dengan proses internal siswa.

Dengan menggunakan metode pembelajaran yang tepat, kegiatan siswa akan senantiasa terwujud. Siswa secara otomatis akan meningkatkan interaksinya dengan materi pelajaran. Interaksi siswa terhadap materi pelajaran bervariasi. Sebagai bentuk kegiatan siswa dalam pembelajaran pula adalah berdiskusi (University of Texas, 2011). Melalui diskusi siswa saling bertukar pengalaman. Bahkan dengan berdiskusi tingkat kegiatan selama pembelajaran dapat mencapai $70 \%$ (Joe Landsberger , 2011).

Dengan demikian berdasarkan beberapa pendapat tersebut di atas dapat disimpulkan bahwa indikator-indikator untuk mengamati keaktifan siswa dalam pembelajaran yaitu a) bertanya b) berpendapat c) menyimak d) menulis e) membaca, dan f) berdiskusi.

Bloom dalam Nana Sudjana (1995) secara garis besar membagi hasil belajar menjadi 3 ranah, yaitu ranah kognitif, ranah afektif, dan ranah psikomotorik. Ranah kognitif, berkaitan dengan kemampuan intelektual. Ranah afektif, berkenaan dengan sikap dan nilai. Sedangkan ranah psikomotoris, merupakan ranah yang berkenaan dengan keterampilan seseorang dalam perbuatan dan kemampuan bertindak secara mandiri.

Robert M. Gagne. Gagne (1985) menyimpulkan ada lima bentuk hasil belajar : a) Kemampuan intelektual, kemampuan memecahkan masalah berdasarkan konsep. b) Strategi kognitif, kemampuan memilah masalah kedalam bagian-bagian yang lebih sederhana, dalam menyelesaikan masalah. c) Informasi verbal, kemampuan untuk menjelaskan kembali informasi yang telah diberikan. d) Kemampuan keterampilan motorik (skill), kemampuan melaksanakan tugas dengan tepat sesuai prosedur. e) Sikap, kemampuan untuk menentukan sikap diri menghadapi berbagai situasi.
Menurut Abdillah (2002), belajar adalah usaha sadar yang dilakukan seseorang dalam perubahan tingkah laku melalui latihan dan pengalaman yang menyangkut aspek kognitif, afektif, dan psikomotorik untuk memperoleh tujuan tertentu (Aunurrahman, 2009: 35).

Sedangkan menurut Hartono, dkk (2012) "belajar merupakan proses mental yang bersifat individual dan sosial yang dipengaruhi oleh faktor lingkungan yang diciptakan oleh pendidik dengan memanfaatkan berbagai media dan sumber belajar" (hlm. 17).

Sehingga dapat dikatakan, belajar adalah usaha sadar dalam perubahan yang terjadi pada seseorang akibat interaksi dengan lingkungan yang diciptakan oleh pendidik.

Metode pembelajaran problem solving dikenal juga dengan metode pemecahan masalah. Dijelaskan oleh Abdul Majid (2012) "metode pemecahan masalah (problem solving) merupakan cara memberikan pengertian dengan menstimulasi anak didik untuk memperhatikan, menelaah dan berpikir tentang suatu masalah untuk selanjutnya menganalisis masalah tersebut sebagai upaya untuk memecahkan masalah" (hlm. 142).

Langkah-langkah dalam problem solving menurut John Dewey (1910) adalah a) menemukan kesulitan b) mengidentifikasi masalahnya c) mengumpulkan berbagai kemungkinan penyebab d) menentukan akar masalah e) membuat kesimpulan penanganan masalah.

Haryanti (2010) melakukan penelitian di SMP Negeri 2 Jatiyoso tahun ajaran 2009/ 2010 menerapkan metode problem solving pada pelajaran IPS. Hasil penelitiannya menunjukkan peningkatan keaktifan siswa dari $71 \%$ menjadi $74 \%$ ( siklus I), padasiklus II $85 \%$. peningkatan pencapaian hasil belajar siswa dari $70 \%$ atau 28 siswa menjadi $80 \%$ atau 32 siswa.

Dengan penerapan Metode pembelajaran problem solving juga, Sriyani (2007) berusaha mengatasi permasalahan pada pada Siswa Kelas XI SMA N 1 Banyudono Tahun Pelajaran 2006/ 2007. Hasil penelitian ini menyebutkan bahwa, penggunaan metode pembelajaran problem solving dapat meningkatkan keaktifan siswa yaitu bertanya dari $0 \%$ menjadi $8 \%$, mengerjakan PR dari $80 \%$ menjadi $100 \%$, menjawab pertanyaan guru dari $4 \%$ menjadi $24 \%$, membawa buku pegangan dari $52 \%$ menjadi $80 \%$, dan masuk kelas tepat waktu dari $84 \%$ menjadi $96 \%$.

\section{METODE PENELITIAN}

Penelitian merupkan jenis Penelitian Tindakan Kelas (PTK). PTK dilakukan dengan urutan kegiatan : (a) perencanaan, (b) tindakan, (c) pengamatan, (d) refleksi.

Subjek penelitian adalah kelas XI TOB SMK Negeri 5 Surakarta. Jumlah siswa kelas tersebut 36 
siswa. Penelitian dilakukan pada semester kedua pada pertengahan bulan April sampai awal bulan Juni 2013.

Data yang diambil adalah data keaktifan dan hasil belajar siswa yang kesemuanya merupakan data kuantitatif. Data keaktifan siswa dijabarkan dengan dua cara, secara jumlah dan mutu. Secara jumlah yakni dihitung berdasarkan persentase jumlah siswa, dan secara mutu yakni dihitung berdasarkan skor keaktifan siswa.

Metode pengumpulan data dilakukan dengan empat cara 1) wawancara berstruktur, 2) observasi, 3) tes, dan 4) angket.

Data penelitian dianalisis menggunakan teknik analisis deskriptif. Analisis deskriptif merupakan teknik analisis bertujuan memberikan deskripsi mengenai subjek penelitian berdasarkan data dari variabel yang diperoleh dari kelompok subjek yang diteliti (Azwar, 2005). Perhitungan statistik sederhana yang digunakan dengan ketentuan :

1. Persentase jumlah keaktifan dijabarkan dengan rumus :

a. Bertanya dan berpendapat: $\frac{\text { Banyak siswa yang bertanya dan berpendapat }}{\text { Jumlah siswa }} \times 100 \%$

b. Menyimak, membaca, menulis, dan berdiskusi :

$$
\frac{\text { Banyak siswa yang memiliki skor } 3 \text { dan } 4}{\text { Jumlah siswa }} \times 100 \%
$$

Hal ini dikarenakan untuk mengimbangi bertanya dan berpendapat secara jumlah.

2. Persentase mutu keaktifan dijabarkan dengan rumus :

$$
\frac{\text { Perolehan skor }}{\text { Skor maksimum } 36 \text { siswa }} \times 100 \%
$$

Kemudian data dikategorikan sesuai dengan kriteria yang telah dirumuskan sebagai berikut :

Tabel 1. Pembagian Kriteria

Persentase Mutu Keaktifan

\begin{tabular}{cll}
\hline Nilai & Batas bawah (Bb) & Batas atas (Ba) \\
\hline D & $\mathrm{M}-1,5 \mathrm{~S}$ & $\mathrm{M}-0,5 \mathrm{~S}(\mathrm{Bb} \mathrm{C})$ \\
\hline $\mathrm{C}$ & $\mathrm{M}-0,5 \mathrm{~S}$ & $\mathrm{M}+0,5 \mathrm{~S}$ \\
\hline $\mathrm{B}$ & $\mathrm{BaC}$ & $\mathrm{M}+1,5 \mathrm{~S}$ \\
\hline $\mathrm{A}$ & $\mathrm{Ba} \mathrm{B}$ & $\mathrm{M}+3,0 \mathrm{~S}$ \\
\hline
\end{tabular}

M : Rata-rata

$\mathrm{S}$ : Simpangan baku

$$
\sqrt{\frac{\sum f x^{2}}{\mathrm{~N}}}
$$

$\mathrm{X}$ : persentase skor

$\mathrm{N}$ : banyak item persentase skor

(Sumber: Sudjana, N. 1995: 122)

Dengan keterangan :
$\mathrm{D}=$ rendah $; \mathrm{C}=$ sedang $; \mathrm{B}=$ tinggi $; \mathrm{A}=$ sangat tinggi

\section{HASIL DAN PEMBAHASAN \\ Kondisi Sebelum Penerapan Problem Solving}

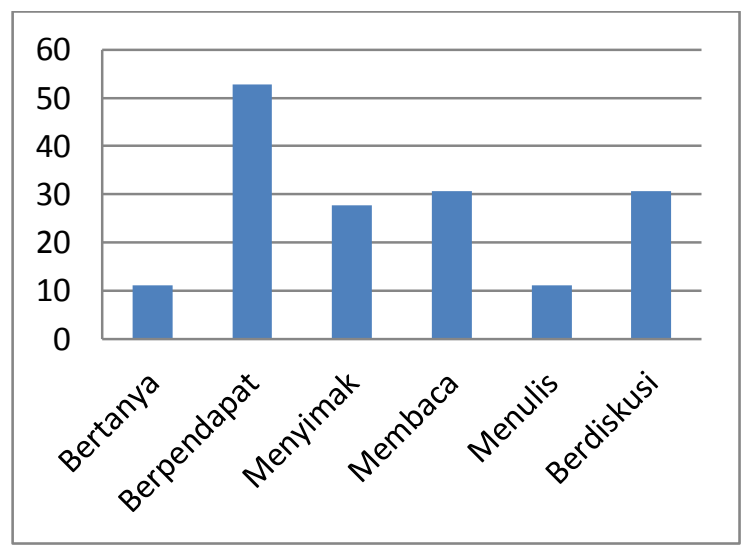

Gambar 1. Grafik Persentase Jumlah Keaktifan Setiap Indikator pada Kegiatan Prasiklus

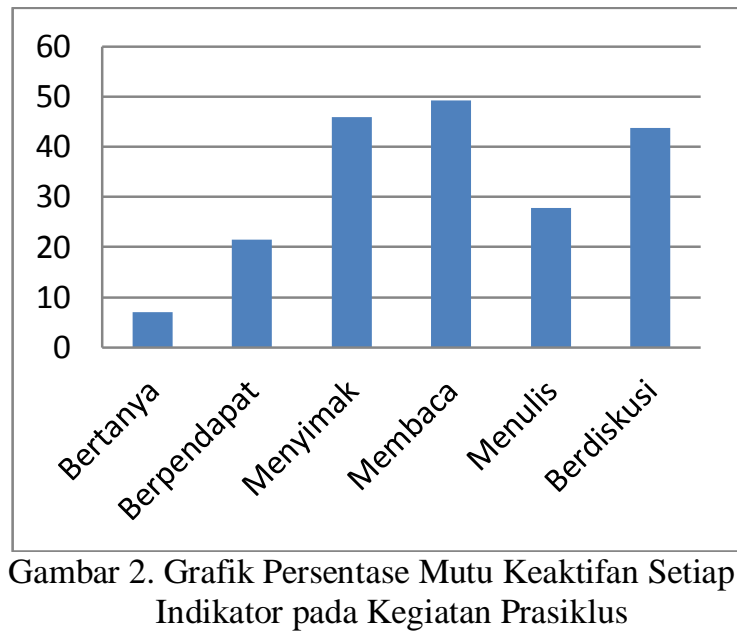

Persentase tertinggi terdapat pada indikator berpendapat $52,78 \%$, namun banyak siswa yang kurang spesifik pendapatnya. Persentase bertanya sebesar $11,11 \%$ dengan pertanyaan yang kurang berbobot, menyimak sebesar 27,78\%, menunjukkan baiknya mereka dalam memperhatikan. Persentase membaca sebesar $30,56 \%$, menulis sebesar $11,11 \%$, dan berdiskusi sebesar 30,56\%.

Hasil belajar siswa masih tergolong perlu untuk ditingkatkan karena dari 36 siswa hanya 55\% yang telah mencapai KKM ( $\geq 75)$, sedangkan $45 \%$ siswa yang lain belum mencapai KKM $(<75)$. 


\section{Penerapan Problem Solving Siklus I}

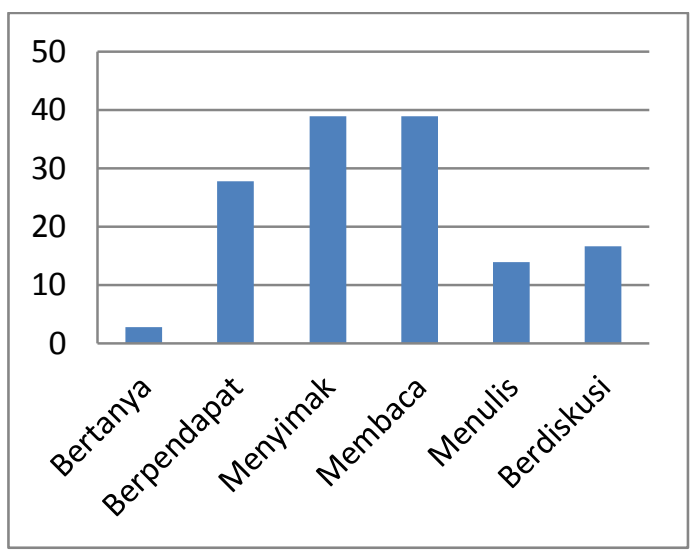

Gambar 3. Grafik Persentase Jumlah Keaktifan Setiap Indikator pada Kegiatan Siklus I

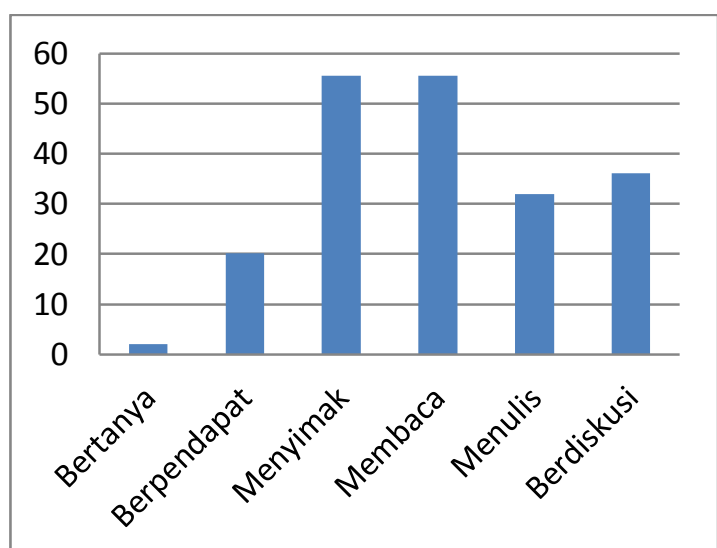

Gambar 4. Grafik Persentase Mutu Keaktifan Setiap Indikator pada Kegiatan Siklus I

Pada kegiatan siklus I persentase jumlah keaktifan menyimak dan membaca masing-masing $38,89 \%$, dengan semakin baiknya mereka dalam memperhatikan. Persentase bertanya sebesar $2,78 \%$, dengan mutu keaktifan tergolong sangat rendah. Persentase berpendapat sebesar 27,78\%, dengan mutu keaktifan tergolong rendah. Persentase menulis sebesar $13,89 \%$, dengan mutu keaktifan tergolong sedang. Persentase berdiskusi sebesar $16,67 \%$, dengan mutu keaktifan tergolong sedang.

Hasil belajar siswa, pada siklus I rata-rata kelas sebesar 77 dan dari 36 siswa, yang telah mencapai KKM terdapat 22 siswa (sekitar 61\%).

\section{Penerapan Problem Solving Siklus II}

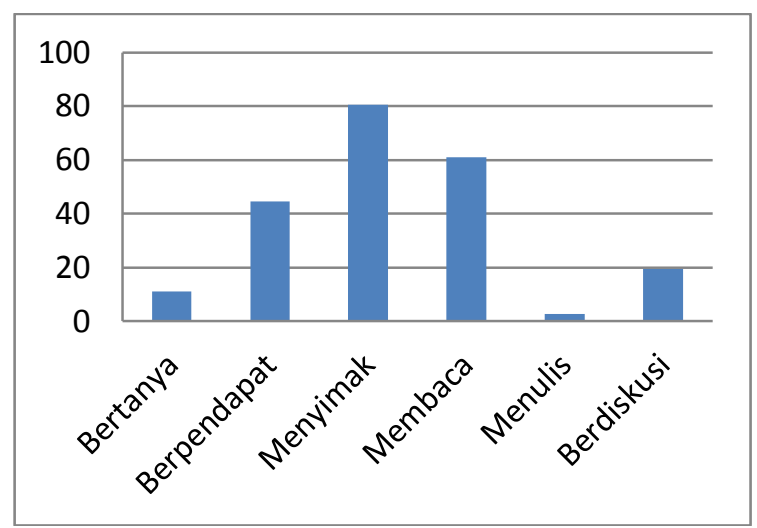

Gambar 5. Grafik Persentase Jumlah Keaktifan Setiap Indikator pada Kegiatan Siklus II

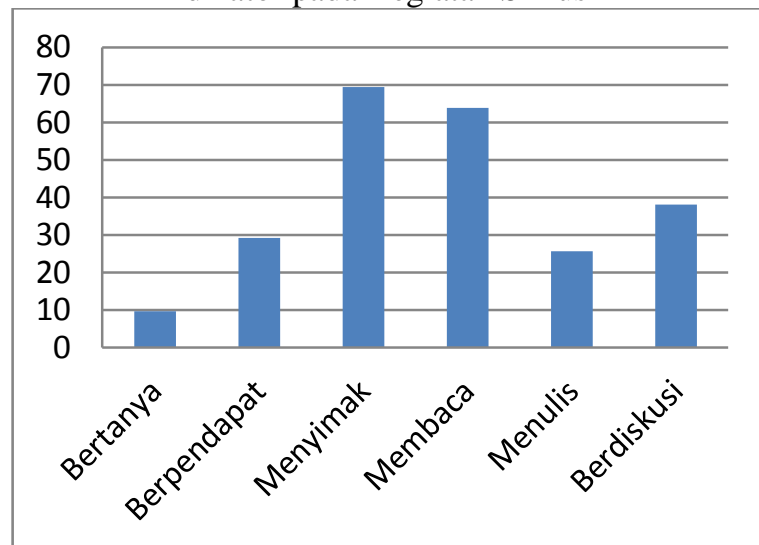

Gambar 6. Grafik Persentase Mutu Keaktifan Setiap Indikator pada Kegiatan Siklus II

Pada siklus II persentase jumlah keaktifan menyimak dan membaca $80,56 \%$ dan $61,11 \%$, dengan mutu keaktifan keduanya tergolong sangat tinggi. Persentase bertanya sebesar $11,11 \%$, dengan mutu keaktifan tergolong rendah. berpendapat sebesar $44,44 \%$, dengan mutu keaktifan yang lebih baik dari sebelumnya. Persentase menulis sebesar $2,78 \%$, dengan mutu keaktifan yang tergolong sedang. Persentase berdiskusi sebesar 19,44\%, dengan mutu keaktifan yang tergolong sedang pula.

Adapun untuk hasil belajar siswa, nilai ratarata kelas pada siklus II sebesar 79. Jumlah siswa yang mencapai KKM pada siklus II sebanyak 28 siswa (sekitar 78\%).

\section{Hasil Wawancara Berstruktur dan Angket Skala Penilaian}

Hasil dari wawancara berstruktur menunjukkan bahwa secara umum siswa merasa tertarik dengan penerapan metode pembelajaran problem solving, karena mereka merasa tertantang. Berdasarkan data hasil pengisian angket skala penilaian, diperoleh informasi bahwa penerapan pembelajaran problem solving dapat mendorong siswa lebih aktif terutama dalam hal bertanya. 
Pembahasan

Tabel 2. Jumlah dan Mutu Keaktifan Siswa Kegiatan Prasiklus-Siklus II

\begin{tabular}{|l|c|c|c|c|c|c|}
\hline \multirow{2}{*}{$\begin{array}{c}\text { Indikator } \\
\text { Keaktifan }\end{array}$} & \multicolumn{3}{|c|}{$\begin{array}{c}\text { Persentase Jumlah } \\
\text { Keaktifan (\%) }\end{array}$} & \multicolumn{3}{c|}{ Mutu Keaktifan } \\
\cline { 2 - 7 } & Prasiklus & Siklus I & Siklus II & Prasiklus & Siklus I & Siklus II \\
\hline Bertanya & 11,11 & 2,78 & 11,11 & rendah & $\begin{array}{r}\text { sangat } \\
\text { rendah }\end{array}$ & rendah \\
\hline Berpendapat & 52,78 & 27,78 & 44,44 & rendah & rendah & sedang \\
\hline Menyimak & 27,78 & 38,89 & 80,56 & tinggi & tinggi & $\begin{array}{c}\text { sangat } \\
\text { tinggi }\end{array}$ \\
\hline Membaca & 30,56 & 38,89 & 61,11 & tinggi & tinggi & $\begin{array}{c}\text { sangat } \\
\text { tinggi }\end{array}$ \\
\hline Menulis & 11,11 & 13,89 & 2,78 & sedang & sedang & sedang \\
\hline Berdiskusi & 30,56 & 16,67 & 19,44 & tinggi & sedang & sedang \\
\hline Jumlah & $\mathbf{1 6 3 , 9}$ & $\mathbf{1 3 8 , 9}$ & $\mathbf{2 1 9 , 4 4}$ & & & \\
\hline Rata-rata & $\mathbf{2 7 , 3 2}$ & $\mathbf{2 3 , 1 5}$ & $\mathbf{3 6 , 5 7}$ & sedang & sedang & sedang \\
\hline
\end{tabular}

Pada tabel 2 memberikan informasi bahwa diantara enam indikator keaktifan yang ada, indikator menyimak dan membaca mengalami peningkatan berurutan, sedangkan pada empat indikator yang lain tidak mengalami peningkatan yang berurutan.

Secara mutu peningkatan persentase secara berurutan juga terletak pada indikator menyimak dan membaca, sedangkan pada empat indikator yang lain tidak mengalami peningkatan yang berurutan.

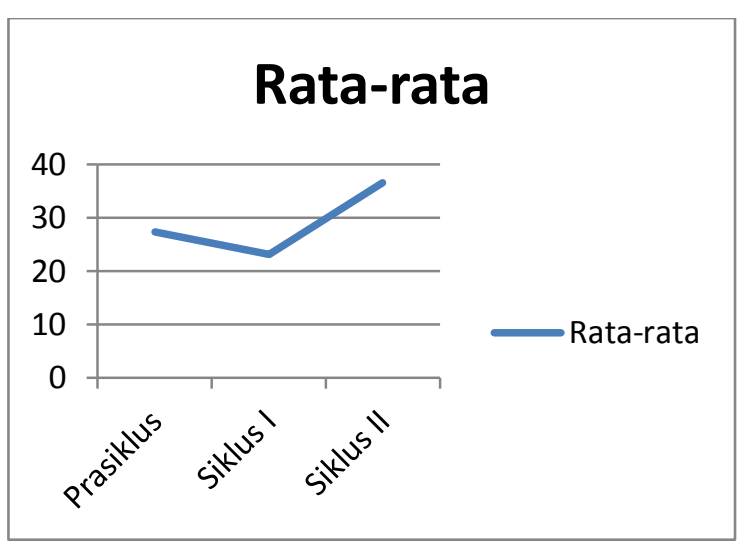

Gambar 7. Rata-Rata Persentase Jumlah Keaktifan Siswa

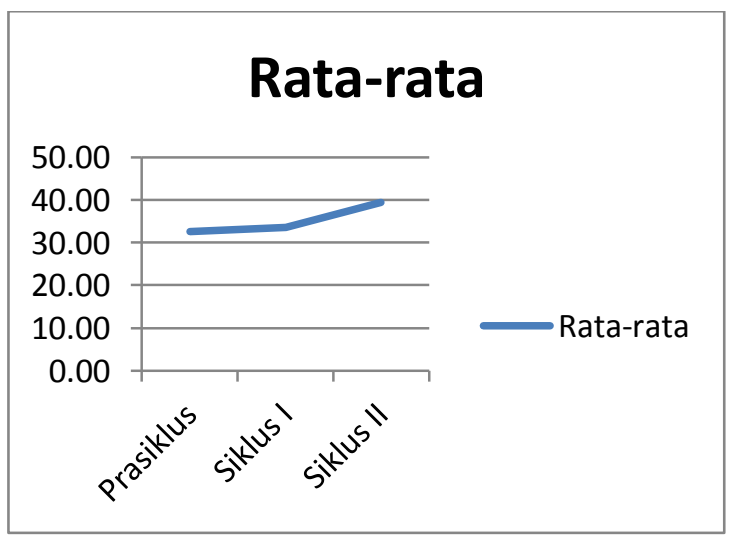

Gambar 8. Rata-Rata Persentase Mutu Keaktifan Siswa
Terjadi peningkatan keaktifan siswa dari kegiatan prasiklus sampai dengan siklus II, baik secara jumlah maupun mutu. Keaktifan ini meningkat terutama pada keaktifan menyimak dan membaca.

Untuk hasil belajar, nilai rata-rata kelas XI TO B mengalami peningkatan. Pada kegiatan prasiklus didapati rata-rata kelas 74, kegiatan siklus I 77, dan pada siklus II 79. Banyak siswa yang mencapai KKM yakni $\geq 75$, mengalami peningkatan dari kegiatan prasiklus sampai siklus II. Pada kegiatan prasiklus jumlah siswa yang mencapai KKM 20 siswa (55\%), pada siklus I 22 siswa $(61 \%)$ dan pada siklus II 28 siswa $(78 \%)$.

\section{KESIMPULAN DAN SARAN Kesimpulan}

Penerapan Metode Pembelajaran Problem Solving dapat meningkatkan keaktifan siswa kelas XI TO B dalam pembelajaran teori, pelajaran kelistrikan otomotif di SMK Negeri 5 Surakarta tahun pelajaran 2012/ 2013. Hal ini terlihat dari rata-rata persentase jumlah keaktifan siswa pada kegiatan Prasiklus $27,32 \%$ dengan mutu sedang, Siklus I $23,15 \%$ dengan mutu sedang, dan Siklus II $36,57 \%$ dengan mutu sedang.

Penerapan metode pembelajaran Problem Solving dapat meningkatkan hasil belajar siswa kelas XI TO B dalam pembelajaran teori pelajaran kelistrikan otomotif di SMK Negeri 5 Surakarta tahun pelajaran 2012/ 2013. Hal ini dapat diketahui dari meningkatnya nilai rata-rata kelas dan jumlah siswa yang mencapai Kriteria Ketuntasan Minimal (KKM). Nilai rata-rata kelas pada Prasiklus 74, Siklus I 77 dan Siklus II 79. Jumlah siswa yang mencapai KKM pada Prasiklus 20 siswa, Siklus I 22 siswa dan Siklus II 28 siswa.

Saran

Untuk meningkatkan kualitas pembelajaran hendaknya 1) siswa berperan aktif selama pembelajaran berlangsung dan tidak malu untuk bertanya. 2) guru banyak mengeksplorasi bahan materi untuk menjabarkan materi yang sederhana, sehingga lebih mudah untuk disampaikan dan mudah untuk dipahami.

\section{DAFTAR PUSTAKA}

Aunurrahman. (2009). Belajar dan Pembelajaran. Bandung: Alfabeta.

Azwar, S. 2005. Metode Penelitian. Yogyakarta: Pustaka Pelajar.

Hartono, dkk. (2012). Paikem (Pembelajaran Aktif Inovatif Kreatif Efektif dan Menyenangkan). Riau: Zanafa.

Kwartolo, Y. (2009). Sembilan Peristiwa Belajar Gagne. Tabloid Penabur Jakarta, 7 (25), 9.

Landsberger, J. (2011). Active Learning. http://www.studygs.net/activelearn.htm diakses 18 November 2012. 
Majid, A. (2012). Perencanaan Pembelajaran Mengembangkan Standar Kompetensi Guru. Bandung: ROSDA.

Muijs, Daniel \& David Reynolds. (2008). Effective Teaching Teori dan Aplikasi. Yogyakarta: Pustaka Pelajar.

Sudjana , N. (1995). Penilaian Hasil Proses Belajar Mengajar. Bandung: Rosda Karya

University of Minnesota, Center for Teaching and Learning. (2008). What Is Active Learning?http://www1.umn.edu/ohr/teachlea rn/tutorials/active/what/index.html diakses pada 18 November 2012.

University of Texas, (2011). Active Learning. http://activelearning.uta.edu/p2.htm diakses pada 18 November 2012.

Warsita, B. (2008). Teori Belajar Robert M. Gagne dan Implikasinya pada Pentingnya Pusat Sumber Belajar. Jurnal Teknodik, 12 (1), 68. 